\title{
PENGEMBANGAN MEDIA “COMIC LIFE” UNTUK GERAKAN LITERASI SISWA KELAS III DI SEKOLAH DASAR
}

\author{
Arina Restian', Eka Kartika Sari² \\ arina.poenya@gmail.com ${ }^{12}$ \\ PGSD, FKIP, Universitas Muhammadiyah Malang ${ }^{12}$
}

\begin{abstract}
Abstrak: Penelitian ini dilakukan dengan tujuan 1) mendeskripsikan bagaimana pengembangan produk media "Comic Life" untuk gerakan literasi siswa kelas III di sekolah dasar dan 2) mendeskripsikan respon pengguna terhadap pengembangan produk media "Comic Life" untuk gerakan literasi siswa kelas III di sekolah dasar. Hasil penelitian ini menunjukkan bahwa: 1) media sudah memenuhi kelayakan dan sesuai dengan kriteria yang ditetapkan, dengan demikian media sudah dapat digunakan untuk kegiatan literasi di sekolah. Hal tersebut didukung dengan perolehan presentase dari ahli media sebesar 90,6\% dengan kategori sangat baik, perolehan presentase dari ahli literasi sebesar 92\% dengan kategori sangat baik; 2) untuk hasil respon dari angket kemenarikan siswa kelompok kecil menghasilkan presentase 93,3\% dengan kategori sangat baik dan hasil respon dari angket kemenarikan siswa kelompok besar sebesar 95,1\% dengan kategori sangat baik.
\end{abstract}

Kata kunci: membaca, literasi, komik

\section{DEVELOPMENT OF “COMIC LIVE” MEDIA FOR CLASS III STUDENT LITERATION MOVEMENT IN ELEMENTARY SCHOOL}

\begin{abstract}
This research was conducted with the aim at 1) depicting how the development of "Comic Life" media products for literacy movements of third-grade students in elementary schools and 2) portraying the users' responses to the development of "Comic Life" media products for literacy movements of third-grade students in elementary school. The results of this research indicate that 1) the media has fulfilled properness and organized criteria so that the media can be utilized for literacy activities in schools. This is espoused by the percentage acquisition of media experts as much as $90.6 \%$ withal excellent category. Moreover, the percentage of literacy experts gain $92 \%$ on the superior category. 2) The response outputs which were acquired from questionnaires of small group students yielded to the tone of $93.3 \%$ in a prime category. Furthermore, the outcomes from the large group questionnaire responses obtain in the tone of $95.1 \%$ on the convenient category.
\end{abstract}

Keywords: reading, literacy, comic 
Arina, Eka, Pengembangan Media (Comic Life)...

\section{PENDAHULUAN}

\section{Latar Belakang}

Pendidikan adalah sesuatu yang melatih kerja keras otot berfikir ekstra berlatih serta mengasah untuk melahirkan kekritisan berfikir. Pendidikan diartikan sebagai usaha yang sangat sadar yang dilakukan oleh keluarga terdekat seperti orang tua baik ayah maupun ibu, selanjutnya masyarakat, dan pemerintah melalui Kemdibud RI, dengan menggandeng sistem pembelajaran baik formal maupun non formal pada kegiatan bimbingan disekolah, pengajaran, dan atau latihan, yang berlangsung di sekolah dan luar sekolah untuk mempersiapkan siswa agar dapat memainkan peranannya secara tepat dalam berbagai lingkungan hidup. Pendidikan di sekolah dasar menjadi tempat yang sangat strategis dalam menanamkan karakter secara kualitas dan kuantitas.

Pentingnya pendidikan di sekolah dasar yang wajib kita fahami bersama dalam dunia pendidikan adalah yang telah termuat dalam kebijakan undang - undang Sistem Pendidikan Nasional (Sisdiknas) Pasal 17 Tahun 2003 Butir 1 dan 2, menyatakan bahwa "pendidikan dasar merupakan jenjang yang melandasi jenjang pendidikan menengah". Pendidikan di sekolah dasar menjadi bagian yang tak terpisahkan membangun karakter Bangsa di tanah Indonesia R.I dalam pentingnya pelaksanaan untuk melahirkan generasi yang berkarakter, unggul dan mandiri serta berkualitas dan juga jenjang pendidikan dasar yang menjadi landasan untuk melanjutkan ke jenjang pendidikan ke tingkatan lebih tinggi.

Pemahaman akan hal tersebut akan membantu pendidik dalam menyiapkan secara inovasi tentang media pembelajaran secara menyengkan gembira dan berbobot dari segi kualitas pengembangan SDM untuk menyeleksi bacaan mereka, namun bukan menjadi kaku ataupun harga mati. Menurut Piaget, tahapan perkembangan intelektual anak pada usia (7 - 11 tahun) yaitu pada tahap operasional konkret. Tahap ini anak sudah dapat melakukan pemecahan masalah sederhana sesuai dengan pendapat atau argumentasi mereka, namun pada tahap ini anak belum mampu berfikir abstrak karena pengetahuan mereka masih terbatas pada situasi konkret, inilah bukti kita sama- sama mencerdaskan kehidupan Bangsa melalui Pendidikan.

Berdasarkan analisis kebutuhan dari hasil observasi awal dan wawancara yang dilakukan oleh peneliti kepada Ibu Puji Astuti, S.Pd pada tanggal 30 Oktober 2018 di SDN Punten 01 Batu, Sekolah Dasar tersebut sudah menerapakan gerakan literasi 
Arina, Eka, Pengembangan Media (Comic Life)...

sekolah. Adapun penerapan gerakan literasi yang pertama, kegiatan membaca buku non pelajaran contohnya buku cerita, fabel, ensiklopedia, biografi maupun novel. Kegiatan tersebut dilakukan selama 15 menit sebelum pembelajaran di mulai. Kemudian, untuk penerapan gerakan literasi sekolah hanya dilaksanakan satu hari dalam satu minggu di hari rabu. Untuk selain hari rabu, siswa melakukan pembiasaan seperti setiap hari jumat seluruh warga sekolah melakukan kegiatan jumat bersih dan juga untuk hari kamis ganjil setiap bulan siswa melakukan sedinten bahasa Jawa (sehari berbahasa Jawa), dan lain sebagainya. Masalah lain yang menjadi kendala dalam penerapan gerakan literasi di sekolah tersebut yaitu ketersedian buku bacaan yang kurang bervariasi membuat siswa merasa kurang antusias untuk membaca.

Pengembangan media comic life sangat dibutuhkan di SDN Punten 01 Batu. Media yang pernah digunakan oleh guru yaitu buku cerita bergambar seperti buku cerita tentang binatang atau fabel. Selain itu, di SDN Punten 01 Batu belum pernah menggunakan media "Comic life" yang di dalamnya terdapat cerita yang begitu dekat dan terjadi dalam kehidupan sehari - hari siswa yang mengandung pesan moral, dan juga memiliki nilai - nilai karakter yang dapat ditanamakan pada diri siswa. Gerakan literasi sekolah ini perlu adanya dukungan dari beberapa pihak antara lain guru, kepala sekolah dan orang tua. Banyak cara yang dapat dilakukan oleh guru untuk mendukung adanya gerakan literasi sekolah, salah satunya dengan penggunaan strategi atau dengan penggunaan media.

Media literasi ini digunakan untuk meningkatkan antusias siswa dalam membaca buku, yang pada akhirnya diharapkan akan dapat menumbuhkan rasa gemar membaca pada siswa. "Kemenarikan suatu media tidak ditentukan dari mahal atau murahnya maupun frekuensi pengguna media tersebut, tetapi tergantung pada kesesuaian antara karakteristik media dengan tahap perkembangan anak termasuk di dalamnya adalah komik" (Saputro \& Soeharto: 2015: 64). Salah satu media pembelajaran di Sekolah Dasar yaitu media pembelajaran menggunakan bahan cetak. Media comic live ini juga termasuk pada media jenis cetak.

Media bahan cetak ini tentunya memiliki kelebihan dan kekurangan dalam penggunaannya. Kelebihannya antara lain dapat memberikan informasi dalam jumlah banyak, mudah dibawa, informasi yang diperoleh disesuaikan dengan minat dan kebutuhan yang akan dipelajari, apabila perlu perbaikan mudah dilakukan revisi. 
Arina, Eka, Pengembangan Media (Comic Life)...

Sedangkan kekurangan media bahan cetak yaitu sulit menampilkan gerak dihalaman cetak, materi terlalu panjang yang ditampilkan oleh media bahan cetak membuat siswa akan cepat bosan.

Oleh karena itu, pengembangan media "comic life" dirasa penting dan sangat cocok untuk menunjang gerakan literasi di SDN Punten 01 Batu karena sekolah tersebut belum pernah menggunakan media bahan cetak berupa komik yang dibuat menggunakan foto asli yang diperankan langsung oleh siswanya. Media "Comic life" ini dapat disebut juga sebagai komik kehidupan karena isi atau konten yang ada di ambil dari kisah hidup atau suatu hal yang terjadi dalam kehidupan sehari - hari. Media ini sangat cocok untuk siswa karena mereka dapat berperan langsung dan membuat siswa menjadi memiliki daya tarik yang tinggi dalam membaca. Dan juga adanya peran langsung dari siswa, membuat siswa lebih cepat memahami pesan dari cerita yang ada pada komik tersebut dan tidak mudah melupakan isi dari cerita komik tersebut.

\section{Gerakan Literasi Sekolah}

Pentingnya pembiasaan literasi membuat Kementrian Pendidikan dan Kebudayaan (Kemendikbud) mengeluarkan Peraturan Menteri Pendidikan dan Kebudayaan No. 23 tahun 2015 yang berisikan pengembangan potensi siswa secara utuh dengan kegiatan wajib 15 menit sebelum pembelajaran di mulai untuk membaca buku non pelajaran (setiap harinya). Penerapan gerakan literasi sekolah meliputi membaca, menulis, melihat dan berbicara.

Berdasarkan hal di atas, dapat diambil kesimpulan bahwasannya gerakan literasi sekolah adalah suatu pembiasaan yang wajib dilakukan oleh sekolah, kegiatan membaca buku non pelajaran dengan waktu 15 yang dilakukan sebelum dimulainya pembelajaran setiap harinya. Ada beberapa aspek dalam literasi, tidak hanya membaca dan menulis melainkan ada berbicara dan melihat guna mendapatkan informasi yang benar dan akurat, sehingga tercipta warga sekolah sekolah yang literat.

\section{Penguatan Pendidikan Karakter}

Peraturan Presiden Repulik Indonesia Nomor 87 Tahun 2017 tentang Penguatan Pendidikan Karakter Pasal 1, menyebutkan bahwa penguatan pendidikan karakter yang disingkat PPK yaitu gerakan pendidikan untuk memperkuat karakter siswa melalui harmonisasi olah hati (etika dan spritual), olah rasa (estetik), olah pikir (literasi dan numerasi) dan olah raga (kinestetik). Penguatan Pendidikan Karakter ini melibatkan 
Arina, Eka, Pengembangan Media (Comic Life)...

kerjasama dengan berbagai antara lain satuan pendidikan, keluarga dan masyarakat. Menurut kementrian pendidikan dan kebudayaan ada lima nilai dalam pendidikan karakter yang utama antara lain religius, nasionalis, gotong royong, integritas dan mandiri.

\section{Media Pembelajaran}

Media berasal dari bahasa Latin yang merupakan bentuk jamak dari kata "medium". Sehingga secara harfiah adalah "perantara" atau "pengantar" (Haryono, 2014 : 47). Oleh karena itu dalam dunia pendidikan, media diartikan sebagai perantara yang dapat digunakan oleh guru untuk menyampaikan pesan atau pembelajaran kepada siswa untuk mempermudah siswa dalam memahami materi tersebut.

Berdasarkan penjelasan di atas dapat disimpulkan media dalah alat atau perantara yang digunakan guru untuk menyampaikan pesan kepada siswa yang sifatnnya memudahkan siswa dalam menerima serta memahami materi yang disampaikan. Dengan adanya media tersebut dapat meningkatkan proses pembelajaran dan juga hasil belajar siswa yang meningkat.

\section{Komik}

Media visual yang telah dijelaskan di atas dapat dibuat dalam bentuk media cetak salah satunya berupa komik. Menurut Saputro \& Soeharto (2015:64), peran dari media komik secara pokok yaitu menciptakan dan meningkatkan minat siswa dalam proses pembelajaran. Sedangkan menurut Indiria Maharsi (2011: 7) komik memiliki arti lebih pada cerita bergambar yang sifatnya menghibur. Namun terlepas dari kedua pengertian tersebut komik merupakan jenis media visual yang diakui mempunyai kekuatan yang besar dalam menyampaikan suatu informasi dan mudah dimengerti. Pendapat Arsyad (2013:89) yang menyatakan siswa sekolah dasar memiliki daya tarik yang tinggi terhadap media visual dan juga cerita yang dihadirkan melalui penokohan dalam komik untuk menyampaikan nilai - nilai karakter pada siswa. Media komik ini diharapkan dapat mempermudah siswa dalam memahami materi pembelajaran yang bersifat abstrak menjadi lebih konkrit yang dekat dengan kehidupan sehari - hari siswa dan bermuatan nilai - nilai karakter.

Berdasarkan penjelasan di atas maka penelitian dengan judul "Pengemabangan Media (Comic Life) Untuk Gerakan Literasi Siswa Kelas III Di Sekolah Dasar" perlu segera dilakukan. Tujuan dari penelitian ini yaitu 1) Mengembangkan media Comic life 
Arina, Eka, Pengembangan Media (Comic Life)...

untuk gerakan literasi siswa kelas III di SD yang valid, 2) Mengetahui respon kemenarikan dari siswa terhadap media Comic Life berdasarkan angket respon siswa.

\section{METODE}

Metode penelitian dan pengembangan Research and Development (R\&D), metode ini digunakan apabila suatu penelitian ingin menghasilkan suatu produk tertentu sekaligus digunakan untuk menguji keefektifan produk (Sugiyono, 2013). Beberapa model penelitian dan pengembangan yang ada, salah satunya yang digunakan dalam penelitian dan pengembangan ini yaitu model Research and Development ( R \& D) dari Borg and Gall. Metode penelitian dan pengembangan menurut Borg, W.R and Gall, M.D ini memiliki langkah - lengkah penggunaan sebagai berikut. 1) potensi dan masalah, 2) pengumpulan data, 3) desain produk, 4) validasi desain, 5) revisi desain, 6) ujicoba produk, 7) revisi produk, 8) ujicoba pemakaian, 9) revisi produk, 10) produksi masal (Sugiyono, 2013).

Pengembangan media komik edukasi ini akan dilakukan oleh peneliti sampai tahap kesembilan karena media ini dirancang sebagai usaha membuat solusi dari permasalahan yang ada. Jadi peneliti tidak melakukan tahap kesepuluh yaitu produksi masal.

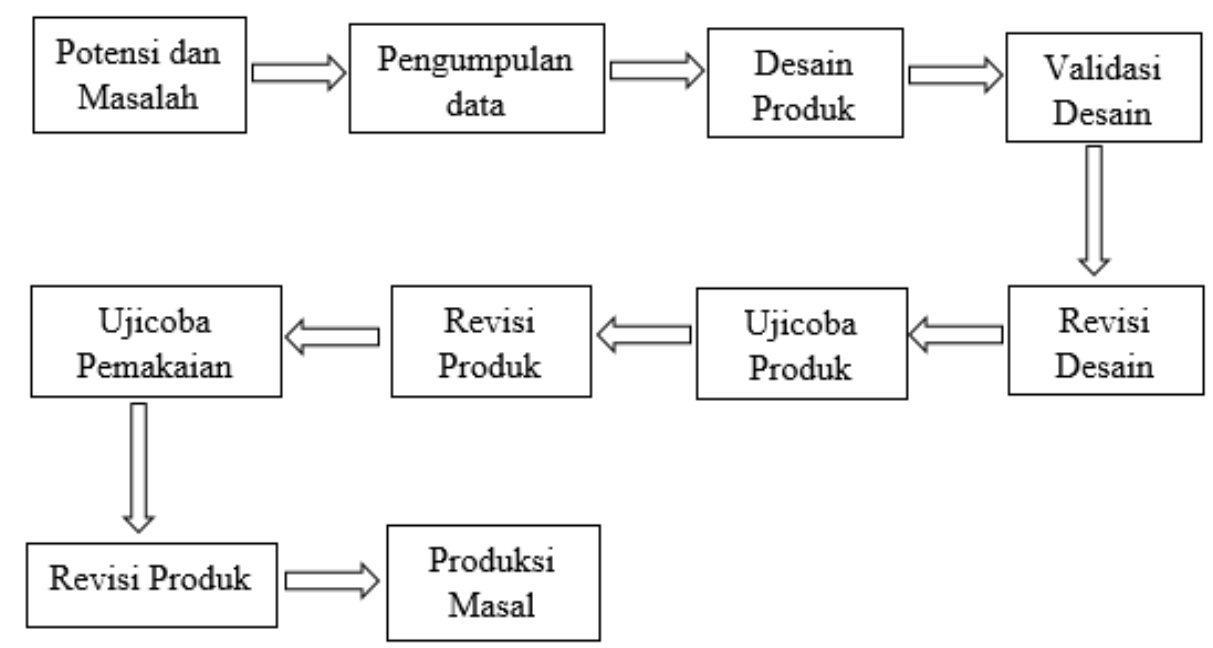

Gambar 1 Tahapan Pengembangan Metode Borg and Gall Sugiyono, 2013 
Arina, Eka, Pengembangan Media (Comic Life)...

\section{HASIL}

Hasil penelitian dan pembahasan tentang pengembangan media dan juga respon siswa terhadap produk "comic life" yang telah dikembangkan oleh peneliti. Berdasarkan penelitian yang telah dilakukan oleh peneliti di SD Negeri Punten 01 Batu yang beralamatkan di Jl. Raya Punten No. 24, Punten, Kecamatan Bumiaji, Kota Batu pada tanggal 26 Februari 2019. Berikut ini penjelasan dri hasil penelitian yang telah dilakukan.

\section{Pengembangan Media "Comic Life" Untuk Gerakan Literasi Siswa Kelas III Di Sekolah Dasar}

\section{Tahap Potensi dan Masalah}

Tahap potensi dan masalah, kegiatan yang dilakukan oleh peneliti pada tahap ini yaitu menganalisa mulai dari kegiatan literasi yang dilakukan oleh siswa kelas III di SDN Punten 01 Batu dan juga menganalisa media yang digunakan untuk gerakan literasi tersebut.

\section{Tahap Pengumpulan Data}

Berdasarkan hasil analisis kebutuhan dan wawancara yang telah dilakukan kepada guru kelas III di sekolah tersebut sehingga mendapat kesimpulan bahwa dibutuhkannya pengembangan media berupa media "Comic Life". Media ini diharapkan dapat digunakan oleh guru kelas untuk memotivasi siswa untuk gemar membaca. Selain itu media "Comic Life" sangat aman untuk digunakan siswa, mudah dan dapat untuk dipindahkan, sehingga media "Comic Life" dapat digunakan oleh siswa dan guru dimanapun dan kapanpun.

\section{Tahap Desain Produk}

Desain media "Comic Life" secara keseluruhan memiliki jumlah halaman 30 dengan ukuran 29,7 cm x 42,0 cm yang dicetak pada kertas HVS 100 gram dengan cover menggunakan kertas krungkut. Lembar 1 merupakan cover dari media "Comic Life", lembar 2 merupakan perkenalan tokoh dalam komik, lembar ke 2-30 merupakan isi cerita dengan judul "Aku Anak Berani Adil, Pemberani, Bertanggung jawab", dan di cover belakang dari media "Comic Life" terdapat sinopsis dari media komik yang telah dikembangkan. Kegiatan yang dilakukan pada tahap ini yaitu mengembangkan desain yang dirancang kedalam bentuk fisik berupa produk. Tahap ini peneliti menggabungkan 
Arina, Eka, Pengembangan Media (Comic Life)... antara teks cerita, desain komik, pemilihan pemain untuk setiap tokoh cerita dan foto siswa yang sebenarnya.

\section{Tahap Validasi Desain}

Validasi dalam pengembangan media Comic Life akan menghadirkan beberapa ahli yang berpengalaman dalam menilai media Comic Life. Ahli media maupun ahli literasi akan menilai hasil dari produk pengembangan media Comic Life sehingga dapat diketahui kekurangan dan kelebihannya. Jika terdapat saran ataupun kekurangan akan dijadikan bahan revisi agar memperoleh produk yang sesuai dengan harapan.

\section{Tahap Revisi Desain}

Tahap revisi desain ini dilakukan peneliti setelah mendapat kritik dan saran dari ahli media. Kritik dan saran ini diperoleh dari kolom kritik dan saran yang telah dituliskan oleh ahli media pada angket validasi ahli media.

\section{Tahap Uji Coba Produk}

Setelah melakukan uji validasi dari para ahli dan melakukan revisi desain. Kemudian dilanjutkan pada tahap uji coba kelompok terbatas. Pada tahap uji coba terbatas ini, media Comic Life yang dikembangkan di implementasikan di Sekolah Dasar. Uji coba kelompok terbatas ini dilakukan dengan jumlah siswa sebanyak 6 orang siswa yang dilaksanakan pada tanggal Selasa, 26 Februari 2019. Implementasi ini dilaksanakan dalam waktu satu hari.

\section{Tahap Revisi Produk}

Tahap revisi produk ini dilakukan apabila pada pengujian terbatas masih terdapat kekurangan dan kelemahan yang diketahui dari saran, catatan pada angket yang disebarkan saat uji coba produk yang dilakukan di SD Negeri Punten 01 Batu.

\section{Tahap Uji Coba Pemakaian}

Tahap uji coba pemakaian ini dilakukan pada siswa kelas III di SD Negeri Punten 01 Batu dengan jumlah awal siswa 26 orang. Implementasi kelompok besar ini dilakukan selama satu hari.

\section{Tahap Revisi Produk}

Tahap revisi produk ini dilakukan apabila pada saat uji coba produk dalam lingkup yang lebih luas terdapat kekurangan dan kelemahan. Dalam uji coba pemakaian, sebaiknya pembuat media komik melakukan evaluasi terhadap produk yang 
Arina, Eka, Pengembangan Media (Comic Life)...

telah dibuat untuk mendapatkan hasil yang maksimal dan media yang layak untuk siswa.

\section{Respon Pengguna Terhadap Pengembangan Media "Comic Life" Untuk Gerakan}

\section{Literasi Siswa Kelas III di Sekolah Dasar}

Respon pengguna digunakan untuk mengetahui kemenarikan media "Comic Life". Angket pengguna diberikan kepada siswa kelas III SD Negeri Punten 01 Batu.

\section{Respon siswa kelompok kecil SD Negeri Punten 01 Batu}

Setelah kegiatan implementasi literasi (membaca buku non pelajaran sebelum pembelajaran dimulai) menggunakan media "Comic Life" selesai. Peneliti meminta siswa untuk mengisi angket respon pengguna terhadap media "Comic Life". Berikut ini hasil angket respon siswa.

Tabel 1 Hasil angket respon siswa (kelompok kecil)

\begin{tabular}{|c|c|c|}
\hline No & Nama & Skor yang diberikan \\
\hline 1. & AMU & 8 \\
\hline 2. & ANH & 10 \\
\hline 3. & EAV & 10 \\
\hline 4. & FCA & 10 \\
\hline 5. & HAR & 10 \\
\hline 6. & SNRP & 8 \\
\hline \multirow{2}{*}{\multicolumn{2}{|c|}{$\frac{\text { Jumlah }}{\text { Presentase }}$}} & 56 \\
\hline & & $93,3 \%$ \\
\hline
\end{tabular}

Presentase respon siswa kelompok kecil $\frac{56}{60} \times 100 \%=93,3 \%$

Berdasarkan tabel 4.12 diperoleh hasil yaitu 93,3\% dengan keterangan media Comic Life yang dibuat atau dikembangkan mendapatkan respon yang sangat baik dari siswa kelas III di SD Negeri Punten 01 Batu.

Respon siswa kelompok besar SD Negeri Punten 01 Batu

Tabel 2 Hasil angket respon siswa (kelompok besar)

\begin{tabular}{|c|c|c|}
\hline No & Nama & Skor yang diberikan \\
\hline 1. & AA & 10 \\
\hline 2. & AAN & 9 \\
\hline 3. & AES & 9 \\
\hline 4. & AMU & 9 \\
\hline 5. & ANH & 10 \\
\hline 6. & APR & 10 \\
\hline 7. & CZE & 10 \\
\hline 8. & DF & 10 \\
\hline 9. & EAV & 10 \\
\hline 10. & EMP & 10 \\
\hline
\end{tabular}


Arina, Eka, Pengembangan Media (Comic Life)...

\begin{tabular}{|c|c|c|}
\hline No & Nama & Skor yang diberikan \\
\hline 11. & FBN & 10 \\
\hline 12. & HAR & 10 \\
\hline 13. & $\mathrm{HPF}$ & 10 \\
\hline 14. & KK & 10 \\
\hline 15. & MAF & 10 \\
\hline 16. & MMF & 10 \\
\hline 17. & MRN & 10 \\
\hline 18. & NAP & 10 \\
\hline 19. & $\mathrm{NSH}$ & 10 \\
\hline 20. & RME & 10 \\
\hline 21. & RRF & 10 \\
\hline 22. & SNRP & 10 \\
\hline 23. & SRS & 10 \\
\hline 24. & VAZ & 10 \\
\hline 25. & VN & 10 \\
\hline 26. & YRT & 10 \\
\hline \multicolumn{2}{|r|}{ Jumlah } & 257 \\
\hline \multicolumn{2}{|r|}{ Presentase } & $95,1 \%$ \\
\hline
\end{tabular}

Presentase respon siswa kelompok besar $\frac{257}{270} \times 100 \%=95,1 \%$

Berdasarkan tabel 4.13 diperoleh hasil yaitu 95,1\% dengan keterangan media Comic Life yang dibuat atau dikembangkan mendapatkan respon yang sangat baik dari siswa kelas III di SD Negeri Punten 01 Batu.

\section{PEMBAHASAN}

\section{Pengembangan Media Comic Life Untuk Gerakan Literasi Siswa Kelas III Di Sekolah Dasar}

Penelitian pengembangan atau yang disebut $\mathrm{R} \& \mathrm{D}$ (Research and Development), peneliti menggunakan model Bord and Gall dengan 10 tahapan. Tahapan pengembangan media Comic Life untuk gerakan literasi di Sekolah Dasar ini meliputi tahap potensi dan masalah, pengumpulan data, desain produk, validasi desain, revisi desain, uji coba produk, revisi produk, uji coba pemakaian, revisi produk, produksi masal. Hal pertama yang dilakukan oleh peneliti adalah analisis kebutuhan yang dilakukan di SD Negeri Punten 01 Batu.

Tahap potensi dan masalah pada penelitian ini dilakukan di SD Negeri Punten 01 Batu. Potensi dan masalah yang ada berdasarkan kondisi nyata di lapangan. Dari kondisi tersebut peneliti melakukan tahap pengumpulan data yang dilakukan melalui observasi dan wawancara dengan pihak sekolah sehingga mendapatkan data yang 
Arina, Eka, Pengembangan Media (Comic Life)...

faktual dan terpercaya. Berdasarkan hasil analisis yang dilakukan di SD Negeri Punten 01 Batu didapatkan hasil bahwa sekolah tersebut memiliki kebutuhan pada media yang digunakan untuk gerakan literasi. Dalam hal ini media yang digunakan untuk gerakan literasi terbatas pada buku yang memiliki tahun terbit lama dan memiliki sedikit variasi jenis buku, selain itu kurangnya fasilitas membuat siswa bosan dan minat membacanya kurang dikarenakan buku bacaan yang sama.

Tahap desain produk ini merancang desain media Comic Life. Pada rancangan media berisikan teks cerita Aku Anak Berani Adil, Pemberani, Bertanggung Jawab. Kegiatan membaca buku non pelajaran akan menyenangkan apabila disajikan dengan menggunakan media yang menarik. Sebelum melakukan implementasi dengan menggunakan media Comic Life, terlebih dahulu melalui proses validasi kepada para ahli validasi. Pada penelitian pengembangan ini peneliti menggunakan ahli media dan ahli literasi sebagai validator media Comic Life yang telah dibuat dan dikembangkan.

Tahap revisi produk ini dilakukan setelah mendapatkan kritik atau saran dari validator ahli media dan ahli literasi. Apabila telah melakukan revisi sesuai dengan saran para ahli dan media dinyatakan valid maka akan diuji cobakan di Sekolah Dasar. Uji coba media Comic Life dilakukan di SD Negeri Punten 01 Batu. Implementasi dilakukan untuk mengetahui respon siswa terhadap penggunaan media Comic Life melalui angket respon siswa. Uji coba produk ini di implementasikan pada kelompok kecil yang berjumlah 6 orang siswa yang mendapatkan hasil presentase 93,3\%.

Tahap uji coba pemakaian ini diimplementasikan pada kelompok besar dengan jumlah siswa 26 orang. Dari angket respon siswa kelompok besar mendapatkan hasil presentase 95,1\%. Dalam uji coba pemakaian, sebaiknya pembuat media komik melakukan evaluasi terhadap produk yang telah dibuat untuk mendapatkan hasil yang maksimal dan media yang layak untuk siswa. Evaluasi dilakukan peneliti pada setiap tahapan yang ada. Hasil evaluasi dilakukan dalam bentuk deskriptif kualitatif dan deskriptif kuantitatif.

\section{Respon Pengguna Terhadap Media Comic Life Untuk Gerakan Literasi Siswa Kelas} III Di Sekolah Dasar

Pengembangan media Comic Life untuk gerakan literasi yang telah diimplementasikan di SD Negeri Punten 01 Batu. Hasil implementasi menunjukkan bahwa media tersebut telah membuat siswa tertarik dan antusias dalam membaca, 
Arina, Eka, Pengembangan Media (Comic Life)...

diketahui juga bahwa pelaksanaan gerakan literasi membaca buku non pelajaran sebelum pembelajaran di mulai menggunakan media Comic Life siswa sangat aktif.

Siswa menyatakan merasa senang dan beberapa dari mereka ingin memiliki media tersebut dirumah. Media Comic Life berbentuk buku komik yang menggunakan foto siswa dan guru sebagai pengisi ilustratornya, begitu pula dengan nama media tersebut yang unik membuat siswa ingin mengetahui isi dari media tersebut. Media Comic Life membuat suasana pelaksanaan gerakan literasi menjadi menyenangkan. Hasil presentase respon siswa kelompok kecil 93,3\% dan hasil presentase respon siswa kelompok besar 95,1\%. Presentase tersebut menunjukkan kriteria sangat baik.

Berdasarkan hasil presentase yang didapatkan, diketahui bahwa media Comic Life dapat digunakan pada kelas III Sekolah Dasar. Implementasi kelompok kecil dan kelompok besar berbeda namun berdasarkan hasil presentase tersebut menunjukkan bahwa media dapat digunakan untuk gerakan literasi membaca buku non pelajaran sebelum pembelajaran di mulai.

\section{SIMPULAN}

Pengembangan media Comic Life melalui beberapa tahapan mulai dari validasi ahli media, validasi ahli literasi, angket respon siswa. Uji validasi ahli media dan ahli literasi digunakan untuk mengetahui kevalidan media Comic Life. Hasil perolehan uji validasi media sebelum revisi adalah $78,6 \%$ dengan keterangan valid, dengan revisi sesuai dengan kritik dan saran, setelah melakukan revisi didapatkan hasil 90,6\% dengan keterangan sangat valid, tanpa ada revisi. Sedangkan perolehan uji validasi ahli literasi mendapatkan hasil nilai 92\% mendapatkan keterangan sangat valid, tanpa ada revisi. kemenarikan media Comic Life diproleh dari implementasi di SD Negeri Punten 01 Batu dengan melakukan uji coba kelompok kecil berjumlah 6 orang siswa memperoleh hasil presentase sebesar 93,3\%. Untuk uji coba kelompok besar berjumlah 26 orang siswa memperoleh hasil presentase sebesar $95,1 \%$.

\section{DAFTAR RUJUKAN}

Arsyad, Azhar. 2013. Media Pembelajaran. Jakarta: PT. RajaGrafindo Persada.

Haryono, Ari Dwi. 2015. Metode Praktis Pengembangan Sumber Dan Media Pembelajaran. Malang: Genius Media \& Pustaka Inspiratif. 
Arina, Eka, Pengembangan Media (Comic Life)...

Maharsi, Indiria. 2011. Komik Dunia Kreatif Tanpa Batas. Yogyakarta: Kata Buku.

Peraturan Menteri Pendidikan dan Kebudayaan Republik Indonesia Nomor 23 tahun tentang Penumbuhan Budi Pekerti.

Peraturan Presiden Republik Indonesia Nomor 87 Tahun 2017 Tentang Penguatan Pendidikan Karakter.

Saputro, Hengkang Bara., Soeharto. 2015. Pengembangan Media Komik Berbasis Pendidikan Karakter Pada Pembelajaran Tematik - Integratif Kelas IV SD. Jurnal Prima Edukasi, 3 (1): 61-72.

Sugiyono. 2013. Metode Penelitian Pendidikan Pendekatan Kuantitatif, Kualitatif, dan $R \& D$. Bandung: Alfabeta 